\title{
FRANJO TUĐMAN IN THE SERBIAN PRESS FROM THE FIRST GENERAL HDZ ASSEMBLY TO THE BEGINNING OF THE SERB REBELLION IN CROATIA*
}

\author{
Željka KRIŽE***
}

\begin{abstract}
This work is devoted to analyzing, in the context of political propaganda and by using selected newspaper and magazine articles, the portrayal of Franjo Tuđman in the Serbian press in the period from the First General Assembly of the HDZ to the beginning of the Serb rebellion in Croatia. The role and purpose of the newspaper and magazine articles in creating a negative image of Franjo Tuđman through a process of artificially constructing an illusion of an enemy is shown and explained. The Serbian press, from the beginning, portrayed Franjo Tuđman as a Croatian nationalist and an enemy of the Serbian people. The media campaign against Franjo Tuđman seamlessly blended in with the patterns of the Greater Serbian propaganda campaign against Croatia. That broader campaign began in mid-1989 and steadily gathered pace. It was fuelled, first and foremost, by negative depictions of the Ustasha regime and the Independent State of Croatia (NDH).
\end{abstract}

Keywords: Franjo Tuđman, Croatia, political propaganda, media, Yugoslavia, Serbia

Translated by Michael Durgo

** Željka Križe, PhD, The Croatian Memorial-Documentation Center of the Homeland War, Zagreb, Croatia 


\section{Introduction $^{1}$}

The treatment lavished on Franjo Tuđman by the Serbian press can only be analyzed and understood within the context of the ubiquitous anti-Croatian propaganda campaign launched and sustained by the Serbian press. That propaganda campaign, it is important to stress, came on the wings of the equally extensive media drive against the Albanians and the media war against Slovenia that preceded and then accompanied the shooting war in the republic. The news reports and stories towed the official line of the Serb authorities led by Slobodan Milošević. The plan was to incite Serb nationalism and form a Serb-dominated unitary Yugoslavia so as to ultimately create a greater Serbian state. The media was to play a crucial role in achieving the objective; it had to create an atmosphere of animosity towards other constituent Yugoslav nations.

The anti-Croatian media campaign began in mid-1989. A daylong event marking the $600^{\text {th }}$ anniversary of the Kosovo battle held on July 9, 1989, and heated debates on the status of the Croatian language formed the backdrop to the launching of the media war against Croatia. Gradually the tone and pitch of the media drive became ever more radical and belligerent. It reached fever pitch between the beginning of 1990 and the first months of $1991 .^{2}$ The foundation stone of the propaganda drive against the $\mathrm{HDZ}^{3}$ party, during the election campaign and especially after the party's victory, was formed by a slew of articles and stories about the crimes of the Ustasha regime. The bylines warned, in turgid prose and with the obvious intention of traumatizing the readership, of genocidal intentions of the new Croatian government. A signif-

\footnotetext{
1 This work (and also the lecture of the same title given at the Discussion Franjo Tuđman 20 years later held in Zagreb on December 10, 2019) is based, for the most part, on sources/newspapers and magazine articles published by Serbian press outlets, some of which are presented in the parts of the chapter 7 of the Željka Križe's PhD thesis entitled Velikosrpska politička propaganda uoči raspada Jugoslavije na primjeru srbijanskoga tiska od donošenja Memoranduma SANU do početka ratnih sukoba u Hrvatskoj (1986. - 1991.) [Greater Serbian Political Propaganda on the Eve of the Disintegration of Yugoslavia from the SANU Memorandum to the Beginning of the War Conflict in Croatia (1986-1991)] (Zagreb: University of Zagreb, Faculty of Croatian Studies, 2015). The underlying scholarly work, however, was expanded in accordance with the subject matter. Thus, additional sources were used and the sources previously presented were analyzed and interpreted again within the framework of this work.

2 Željka Križe, Velikosrpska politička propaganda uoči raspada Jugoslavije na primjeru srbijanskoga tiska od donošenja Memoranduma SANU do početka ratnih sukoba u Hrvatskoj (1986. - 1991.) [Greater Serbian Political Propaganda on the Eve of the Disintegration of Yugoslavia from the SANU Memorandum to the Beginning of the War Conflict in Croatia (1986-1991)], PhD thesis (Zagreb: University of Zagreb, Faculty of Croatian Studies, 2015), pp. 201-209., URL: https://urn.nsk.hr/urn:nbn:hr:111:907689
}

3 Hrvatska demokratska zajednica [Croatian Democratic Union] 
icant number of the Serbs in Croatia drank the Kool-Aid. For them, the fact that the HDZ won a landslide victory in the elections meant that the Croatian nation posed a clear and present danger to all Serbs living in Croatia. ${ }^{4}$

Franjo Tuđman, as the President of the HDZ and later as the President of the Presidency of Socialist Republic Croatia, was mercilessly defamed by the Serb propaganda machine to the point where he became, in the eyes of the Serbs opposed to the new Croatian government, the personification of everything the Serb press invented and consequently treated with opprobrium.

The purpose of this work is to show, within the historical circumstances and chronological context in question, what rhetorical dynamic and what patterns the political propaganda machine of the Serbian regime employed against Franjo Tuđman. The break-down of the rhetorical means in this work follows the system for researching hate speech and identifying systems of discourse in the media developed by the sociologist Zdenka Milivojević. Stjepan Gredelj used Zdenka Milivojevićs system in his lecture on hate speech in the media at the Discussion on Politika's section Opinions and reactions, which I used as a source for my $\mathrm{PhD}$ thesis. The rhetorical means utilized in the media were: key symbols (freedom, dignity, liberation, homeland), metaphors (Kosovo drama, the cradle of Serbdom, holy bones, wild hordes, unarmed civilians...), negative clichés (irredentists, counter-revolution, separatists of all hues, destroyers of Yugoslavia, terrorists, genocidal Croats), loanwords (phalangists, blackshirts, armada...) use of adjectives (monstrous, bestial, bloodthirsty) neologisms, ${ }^{5}$ (Tuđmanists, hadezeovci (members and supporters of the HD party) zengovci (members of the Croatian National Guard)

Articles from the three most widely distributed Serb publications are analyzed in this work. ${ }^{7}$ Two daily newspapers: Politika and Večernje novosti, and one weekly magazine: NIN. Politika and NIN were published by the Politika publishing house and Večernje novosti existed under the auspices of the Novosti publishing house. In this work more space is given to Politika because it was the most influential and respected daily newspaper in Serbia. The public, for the most part, accepted everything they read in the newspaper

\footnotetext{
$4 \quad$ Ibid., pp. 232-274.

5 neologism (Stefan Rittgasser, "Nove jednorječnice u jezikoslovnom nazivlju” [New oneword Lexemes in Linguistic Terminology], Časopis za kulturu hrvatskoga književnog jezika 58 (October 2011), No. 4: 124.

6 Stjepan Gredelj, “Mediji, populizam i govor mržnje” [Media, Populism and Hate Speech], in: Okrugli sto: Odjeci i reagovanja (Belgrade, 2001), pp. 61-63.

7 Sabrina P. Ramet, Balkanski Babilon: Raspad Jugoslavije od Titove smrti do Miloševićevog pada [Balkan Babel: The Disintegration of Yugoslavia from the Death of Tito to the Fall of Milošević] (Zagreb: Alinea, 2005).p. 65.
} 
at face value. As such, the newspaper was an excellent tool for shaping public opinion. ${ }^{8}$

\section{Introducing Franjo Tuđman to the Serbian Public}

Franjo Tuđman was introduced to the Serb public at the beginning of March 1989 in relation to a public discussion of the Društvo književnika Hrvatske (Croatian Writers' Association). The discussion coincided with a rally in Knin staged as a show of support for the Kosovo Serbs (February 28, 1989). Serb nationalist slogans were prominent at that rally. ${ }^{9}$ The media did not give much attention to the gathering in Knin. The tenor of the rally was decidedly anti-Croatian but the Serb media outlets omitted that fact. On the other hand, the public discussion held by the Croatian Writers' Association garnered a lot of attention by the Serb media.

The Croatian Writers' Association's public discussion was used as a platform to introduce the HDZ party, before its founding assembly, to the Croatian public. The HDZ chose the event for its popularity and because some of

\footnotetext{
8 Aleksandar Nenadović, "Politika u nacionalističkoj oluji”, in: Srpska strana rata: Trauma i katarza u istorijskom pamćenju [Politika in a Nationalistic Storm: Serbian Side of the War, Trauma and Catharsis in Historical Memory] (Belgrade: Republika, Vikom grafik, Građanska čitaonica Zrenjanin, 1996), pp. 583-610.
}

9 Rallies in support of the Kosovo Serbs and the Serbian leadership were organized throughout the country after the Kosovo miners went on hunger strike in Stari trg demanding the resignation of the Kosovo political leadership (Rahman Morina, Ali Šukrija, Husamedin Azemi), reinstitution of autonomy guaranteed by the 1974 Constitution and internationalization of the Kosovo question through the agency of the United Nations. Laura Sliber, Allan Little, Smrt Jugoslavije: Svjedočanstva [Death of Yugoslavia: Testimonies] (Opatija: Otokar Keršovani, 1996), 52; Workers from the TVIK nuts and bolts factory went on strike and were joined by workers from Jadran factory (located in Kistanje) and the Gips factory (located in Knin), demanding the resignation of the Knin political leadership "because the politicians did not care about the workers". According to the journalist Srđan Radulović, 5,000 people attended the gathering. Those present shouted slogans in support of Slobodan Milošević, Stipe Šuvar, Rahman Morina, brotherhood and unity and good Albanians. The gathering, however, soon deteriorated into a show of support for the Serbs in Croatia. The Croatian political factors viewed the event in a negative light. The demonstrators demanded, among other things, that the Knin political leadership collectively resign. The Knin Political Organ analyzed the rally and connected the opinions of the speakers with those espoused in the SANU memorandum. Srđan Radulović, Sudbina Krajine [The Fate of Krajina] (Belgrade: Dan Graf, 1996), pp. 11-12; Željka Križe, Velikosrpska politička propaganda uoči raspada Jugoslavije na primjeru srbijanskoga tiska od donošenja Memoranduma SANU do početka ratnih sukoba u Hrvatskoj (1986. - 1991.) [Greater Serbian Political Propaganda on the Eve of the Disintegration of Yugoslavia from the SANU Memorandum to the Beginning of the War Conflict in Croatia (1986-1991)], pp. 157-160. 
the members of the Initial circle for founding the HDZ were also members of the Croatian Writers' Association. The opening speech of the discussion was held by Franjo Tuđman who received a standing ovation. In his speech Franjo Tudman pointed out that the appearance of the HDZ in the political arena was perceived as a portent of Croatia's awakening and asserted that Croatia had existed under a dictatorship for too long and that that dictatorship had had its day because the social and political realities in the SFRY had reached a boiling point and the opposing tendencies of Serbia and Slovenia were tearing the social and political fabric of the country apart. Tuđman qualified these statements by stating that the time for the emergence of a democratic movement that would express the opinions and aspirations of the majority of the Croats was long overdue and that these opinions and aspirations were explained in the Draft HDZ Political Platform. He warned that the pervasive unreasonable attitudes plaguing the political discourse in the SFRY were pitting nations in Yugoslavia against one another and that the situation, in that particular regard, was especially dangerous in Kosovo. Not mincing words Tuđman opined that a resolute 'no' should be said to those wishing to impose the methods of the Chinese revolution on Bosnia and Herzegovina, Croatia and Slovenia for the purpose of forcing their neo-Stalinism and neo-unitarism on the whole country. ${ }^{10}$

An article in Politika, entitled "The Familiar Maspok Platform" described the discussion of the Croatian Writers' Association. ${ }^{11}$ The byline lists the key, in his opinion, motifs of Tuđman's speech and points out that Tuđman explained in detail how the Croatian nation is not sovereign. On the basis of that the byline concludes that "there is no doubt that confederacy is a mild description of the form of Yugoslavia Tuđman advocates and it is clear that the ultimate objective is Croatia's full independence on the basis of the ideas of Ante Starčević whom Tuđman, in his speech, often mentioned. Stjepan Radić also featured prominently in Tuđman's elaboration". ${ }^{12}$

The tenor of the article in Politika was, for the most part, objective and reserved and focused mostly on reporting without trying to characterize Franjo Tuđman. On the other hand, an article in NIN, about the same subject, exco-

\footnotetext{
10 "Političko ozračje u vrijeme osnivanja početnog djelovanja Hrvatske demokratske zajednice"[Political atmosphere at the time of the forming and initial activities of the DZHHDZ party]. Ivo Perić, Spomen knjiga: Deset godina Hrvatske Demokratske zajednice [Commemorative book, Ten years of the HDZ party], ed. Anđelko Mijatović, (Zagreb: Hrvatska demokratska zajednica, 1999.), 47-48.

11 Maspok - abbreviation for "masovni pokret" (mass movement), used in Serbia for the 1971 Croatian Spring movement.

12 R. Arsenić, "Na poznatoj platformi "maspoka“" [The Familiar Maspok Platform], Politika (Belgrade), No. 27084, March 2, 1989, p. 20.
} 
riated Franjo Tuđman, the Croatian Writers' Association and Croatia. It was entitled "Maspok Vampires". Right off the bat the byline states that a political party is being formed in Croatia "under the leadership of the infamous Franjo Tuđman, a veteran of the Maspok revolution in Croatia". The article then proceeds to educate the younger generation and those with short memories about Franjo Tuđman, a "prominent Maspok member", "ambitious Croatian national socialist". The author correctly states that Tuđman was a communist, general and historian. However, he sophistically qualifies these facts by stating that Tuđman "is a historian without a precedent" because he "discovered" the truth about the Jasenovac camp. According to the author, Tuđman minimized the number of victims at the Jasenovac camp and characterizes Tuđman's findings as "cannibalism against Serbs". The colorful description of Tuđman ends with an assertion that Tuđman was convicted for his "treasonous and nationalistic" actions which were undertaken from "the position of Croatian Fascism". "He served his sentence, but the time spent behind bars did not rehabilitate him," the author concludes and proceeds to excoriate the other participants in the public discussion and their speeches and statements. The author calls them "proven nationalists" and their ideas he dubs "nationalist program". Finally, the author pronounces that the public discussion was a "nocturnal vampires' ball". 13

Večernje novosti entitled their article about the public discussion "An Appeal for Destroying Yugoslavia". It is stated in the article that "former Maspok members' performances were militant" and that they "called on everyone to participate in the destruction of Yugoslavia and the Communist Party". The article is replete with vituperative attacks on the participants in the public discussion. Fatuous comments also feature prominently. The author claims that the volume of "ominous and haranguing" sentences "had not been heard in Croatia and Zagreb since the end of WWII" and that "the participants frenetically welcomed" every assertion about how "Croatia had been oppressed" and how the "Croatian nation is in great peril". In the article Franjo Tuđman is described as the leader of "an imposing group of Maspok members" and also obviously "the main ideologue of the movement". It has to be pointed out that, unlike NIN, Večernje novosti chose to write about Franjo Tuđman in sarcastic terms, shying away from outright accusations and vituperative qualifications. Večernje novosti reported that Franjo Tuđman had mentioned in his speech the "Croatian people", "the Church", "nobility" and "unity with the Serbian nation". ${ }^{14}$

\footnotetext{
13 Petar Ignja, "Vampiri maspoka" [Maspok Vampires], NIN (Belgrade), No. 1993, March 5, 1989, p. 12.

14 J. Kerbler, "Poziv na rušenje Jugoslavije” [An Appeal for Destroying Yugoslavia], Večernje novosti (Belgrade), No. 23402, March 1, 1989, p. 15., Željka Križe, Velikosrpska politička pro-
} 
The tenor of the articles about Franjo Tuđman in the Serb media varied. However, all the bylines depicted him as a nationalist, or worse. The measure of Tuđman's connection to the 1971 Croatian Spring movement and the Ustasha movement depended on the proclivities of the authors and editorial policies of a given publication. Regardless of the level of fatuousness displayed by the bylines, however, every article played on the collective trauma of the Serb people and thus disqualified Tuđman as a relevant political factor and portrayed him as a visceral enemy of Serbdom. The authors used the neologism Serb-eaters and the negative cliché national socialist with abandon.

\section{Franjo Tuđman during the election campaign in Croatia}

After the presentation of the HDZ's political platform at the public discussion of the Croatian Writers' Association, the Serb media again shifted their attention to the situation in Kosovo and the political conflict with Slovenia. The gaze of the Serb media returned to the HDZ and Franjo Tuđman with the commencement of the election campaigns in Croatia.

On February 23, 1990, the President of the Assembly of the Socialist Republic of Croatia Anđelko Runjić, passed, in accordance with the previously accepted Amendments to the Constitution of the Republic of Croatia from February 14 and the Decree of declaring the Law on appointing and recalling members of the Assembly from February 17, the Decision on announcing the elections for members of the Assembly of the Socialist Republic of Croatia. The election campaigns were set to start. ${ }^{15}$

The upcoming elections provided the context for the HDZ's First General Assembly, held in the Vatroslav Lisinski concert hall in Zagreb on February 24 and 25. 1760 delegates participated. Also present were citizens-observers, guests and reporters. The Assembly was opened by Franjo Tuđman and his speech was often interrupted by applause and ovations. ${ }^{16}$

Weekly and daily publications ran a flurry of articles about the Assembly but the focal point of the media attention was one sentence in Franjo Tuđman's

\footnotetext{
paganda uoči raspada Jugoslavije na primjeru srbijanskoga tiska od donošenja Memoranduma SANU do početka ratnih sukoba u Hrvatskoj (1986. - 1991.), pp. 160-161.

15 Domovinski rat: Pregled političke i diplomatske povijesti [The Homeland War: An Overview of the Political and Diplomatic History], prepared by Ante Nazor and Tomislav Pušek (Zagreb: Globus, HMDCDR, 2018.), p. 29.

16 Ivo Perić, "Političko ozračje u vrijeme osnivanja početnog djelovanja Hrvatske demokratske zajednice”, Spomen knjiga: Deset godina Hrvatske Demokratske zajednice, ed. Anđelko Mijatović (Zagreb: Hrvatska demokratska zajednica, 1999.), p. 76.
} 
speech in which he drew attention to criticism lavished on the HDZ's perceived objectives and pointed out that the flawed perceptions were grounded in faulty understanding and misinterpretations of various sources and that the advocates of the hegemonistic-unitarist or greater Yugoslav options, thus creating an illusion that the $\mathrm{HDZ}$ was bent on recreating the Ustasha regime. Tuđman stressed that "the $\mathrm{NDH}^{17}$ was not just a Quisling polity and Fascist crime, but also an expression of political aspirations of the Croatian people and their desire for independence and a manifestation of the objectives of Nazi Germany which was seeking to create a new European order on the ruins of the Versailles peace". Tuđman concluded that "the creation of the NDH did not take place as a result of a mere whim of the Axis powers but came about through an interplay of specific historical factors". ${ }^{18}$

In his speech Tuđman mentioned AVNOJ ${ }^{19}$ and $\mathrm{ZAVNOH}^{20}$, emphasizing that the HDZ political platform is built on three important elements and determinants of contemporary Croatian history: "the ideas of Ante Starčević in the context of Croatian historic rights, the ideas of Stjepan Radic in the context of humanist republicanism and on the positive core of the traditions of the Croatian left which insisted on the right of the Croatian people to self-determination; the right that is ingrained in the principles of AVNOJ and ZAVNOH Croatia but obfuscated by a single-party centralism and utopian incongruities of the Communist regime". ${ }^{21}$

However, the Serb media completely excluded the above part of Tuđman's speech from their reports and articles and focused exclusively on the sentence in which the NDH is connected to the aspirations of the Croatian people for independence. It was that sentence, and that connection, that served as the source of every interpretation of what happened at the Assembly and as evidence that the HDZ party's platform was formed on the ideology of the Ustasha movement and that one of its objectives could well be the resurrection of the Ustasha movement. The Serb media identified Franjo Tuđman as the key person in that process.

\footnotetext{
17 Nezavisna Država Hrvatska [Independent State of Croatia]

18 "Programske zasade i ciljevi HDZ: Uvodno izlaganje dr. Franje Tuđmana" [Political platform and objectives of the HDZ: Introductory speech by Franjo Tuđman], Glasnik Hrvatske demokratske zajednice (Zagreb), No. 8, March 1990, pp. 17-21.

19 Antifašističko vijeće narodnog oslobođenja Jugoslavije [Anti-fascist Council of the People's Liberation of Yugoslavia]

20 Zemaljsko antifašističko vijeće narodnog oslobođenja Hrvatske [Land's Anti-fascist Council of the People's Liberation of Yugoslavia]

21 Ivo Perić, "Političko ozračje u vrijeme osnivanja i početnog djelovanja Hrvatske demokratske zajednice”, in: Spomen knjiga: Deset godina Hrvatske demokratske zajednice, 7.
} 
Večernje novosti drew attention to the Assembly story by placing a huge headline in the top right corner of the front page. The headline read: "Discreet Taste of the NDH". It was followed by misquoting what Tuđman had said at the Assembly: "The NDH was not just a Quisling-Ustasha polity, it was part and parcel of the centuries long desire of the Croats", ${ }^{22}$ The misquote was deliberate. Večernje novosti again used the tool of sarcasm: “Tuđman's allocution lasted an hour, but he did not say much. Basically, he postulated his aim to secede Croatia from the future confederation and that was that. He could have said that in a matter of seconds. ${ }^{23}$ The headline of an article about the second day of the Assembly was also given pride of place on the front page. It read, "God and Croats Again." The byline placed the HDZ firmly within the context of chauvinism and racial hatred and equated the members of the HDZ with the supporters of Vuk Drašković, the president of the Serbian Renewal Movement and pointed out that "dangerous messages, aimed at Croats in Croatia and abroad, were voiced by Tuđman's supporters at the Assembly' were heard at the Assembly". ${ }^{24}$

NIN devoted the whole front page to the event. The graphic design featured an egg in a cup, broken in the shape of a swastika, on a black background. The headline read: "HDZ and NDH - Where is Tuđman's Program Heading". ${ }^{25}$ The Assembly was the main theme of the whole issue. The issue, as such, was entitled Our theme. In the introductory article, entitled "The $\mathrm{HDZ}$ and the NDH", the byline correctly quoted Tuđman's sentence about the $\mathrm{NDH}$ and concluded that the sentence openly showed that the Ustasha NDH represented one point in the continuum of the desire to realize the Croatian historic right and that the eradication of that particular point in $1945 \mathrm{did}$ not mean the cessation of the continuum itself. ${ }^{26}$ Attached to a follow-up article, entitled "It Happened in the Lisinski Hall" was a geographical map of Croatia over which was drawn a knife with the letters NDH on the handle. The byline condemned Tuđman's sentence about the NDH and drew attention to Tuđman's geographical pretentions towards Bosnia. ${ }^{27}$

\footnotetext{
22 "Diskretni okus Endehazije" [Discreet Taste of the NDH Regime], Večernje novosti (Belgrade), No. 23722, February 25, 1990, front page.

23 D. Glušćević, “Diskretni okus Endehazije”, Večernje Novosti (Belgrade), No. 23722, February 25,1990 , p. 9.

24 D. Gluščević, "Opet Bog i Hrvati”, [“God and Croats Again”] Večernje Novosti (Belgrade), No. 23723, February 26, 1990, p. 4.

25 NIN (Belgrade), No. 2044., March 4, 1990, front page

26 Milorad Vučelić, “HDZ i NDH”, NIN (Belgrade), No. 2044, March 4, 1990, p. 9.

27 Vesna Knežević, “Tako je bilo u Lisinskom” [That's How it Was in the Lisinski Hall], NIN (Belgrade), No. 2044, March 4, 1990, pp. 10-11., Željka Križe, Velikosrpska politička propaganda uoči raspada Jugoslavije na primjeru srbijanskoga tiska od donošenja Memoranduma SANU do početka ratnih sukoba u Hrvatskoj (1986. - 1991.), p. 237.
} 
Another article, entitled "Metamorphosis of a General" was devoted solely to Tuđman. A photograph of Tuđman on a dais accompanied the article. The caption read: "A new Croatian Ban, Franjo Tuđman". The rhyme was meant to be derogatory, and it was repeated in the article itself. The byline posed the following question: "Can a man who waged a war against the monstrous $\mathrm{NDH}$ for four years defend, 45 years later, the intent to reform that very monstrosity?" The article provides a detailed biography of Tuđman which correctly gives the village of Veliko Trgovišce in the Croatian Zagorje region as his place of birth. In the brackets the author states that the fact is important because it shows that Tuđman, contrary to popular opinion, is not from Herzegovina. The article unambiguously condemns Franjo Tuđman for downplaying the number of Jasenovac victims in his book Bespuća povijesne zbiljnosti [Wastelands of Historical Reality], for claiming that Tito's Partisans killed a large number of captured Ustasha soldiers at Bleiburg and for his open admiration for cardinal Stepinac. When referring to Franjo Tuđman as historian the byline puts the word under quotation marks. Tuđman's scholarly efforts receive the same treatment. The author, in an attempt at witticism, states that the main enemy of Tuđman's scholarship is actually the 1960s incarnation of Tuđman and affirms that that earlier incarnation of Tuđman, in his book Stvaranje socijalisticke Jugoslavije [Creating the Socialist Yugoslavia], stated that 3,750,000 people were killed. The stylistic tenor of the article is one of febrile lyricism. For Franjo Tuđman, according to the author's caustic attitude, socialism was, for 30 long years, the shiny tip of the only viable social structure but, alas, in the here and now his "followers" are taken to violent outbursts at every mention of Yugoslavia. The author explains how the imposing presence of Franjo Tuđman, a "former brigand" imbues the HDZ members with confidence and concludes his piece by asserting that "Mister Franjo Tuđman" is in good health, exteriorizes aspirations of leadership and lives in a villa in the upscale part of Zagreb. ${ }^{28}$ The author of the article was, at the time, NIN's Zagreb correspondent and the article, apart from the introductory paragraph, was written in Croatian. These two facts, the editors evidently believed, would prove the veracity of the author's claims to the public.

For a few days after the Assembly in the Lisinski hall the Serbian media continued to run articles about the event, informing the public of how various state organs, institutions, associations and individuals reacted to what had been said at the Assembly. These reactions were all negative. Readers' letters, published in Politika's sections Between us and Opinions and reactions, played a significant role in the defamation campaign against Franjo Tuđman. A letter from the Serbian author Radomir Smiljanić entitled "The Serb will not

${ }_{28}$ Ratko Dmitrović, "Metamorfoza jednog generala" [A Metamorphosis of a General], NIN (Belgrade), No. 2044 March 4, 1990, pp. 10-11. 
finance Tuđman's NDH" was published in the "Between us" section. Smiljanić characterizes the HDZ Assembly as neo-Nazi and Tuđman as "a former Partisan general", "apparatchik", and a member of the clique that ushered in the collapse of Yugoslavia and consequent chaos. He compares the atmosphere at the Assembly with what went on in "Hitler's pubs" and claims that the participants, including "Ustashas" welcomed Tuđman's proclamation of "the historic desire of the Croatian people to have a genocidal, criminal and Nazi independent Croatia". Also, Smiljanić theorizes that "those other followers of Tuđman, those from the Brioni islands" who prevented one Nuremberg process from taking place, "those committed Nazis and mass murderers who committed crimes against three peoples in the NDH, the Serbs, the Roma and the Jews" have a secret plan and that the plan is in the process of being realized". Finally, he emphasizes that many Serbs, "the remnants of the slaughtered Serb masses in Croatia" have telephoned him and expressed their bitterness and points out that many of them want to close their bank accounts in Croatia because they don't want to finance "Tuđman's NDH". Smiljanić, in this context, mentions Ivica Račan and poses the questions many Croatian Serbs have allegedly asked: "Should we allow our money to be used for the creation of a neo-Pavelić, but this time Tuđman, Đodan and Šeks led NDH? Should we allow our money to be used for purchasing weapons and knives which will be used to kill and slaughter us?" Smiljanić rounds up his argument by concluding that the Serbs have to defend themselves against Fascism in the north and in the south and that the time has come for the Serbs to fight for their cultural and political autonomy in Croatia because autonomy is the only thing that can protect their lives and ensure their freedom and democratic society. ${ }^{29}$

In another letter, published in the "Opinions and reactions section", entitled "The spiritual father of Franciscan pogroms and Ustasha genocide against the Serbs", which refers to Ante Starčević, the reader expresses his dismay at the fact that Franjo Tuđman mentioned Ante Starčević in his speech. The reader claims that Ante Starčević imbued many Croats with vitriolic hatred of Serbs and that that hatred is akin to "the lowest instincts of a beast" and that Starčevićs writings inspired the Ustasha to kill, in Jasenovac only, a million Serbs. In the concluding part of the article, the reader warns that the HDZ is proud of Starčević and the NDH and that the party is preparing "another massacre of Serbs in Croatia and Bosnia and Herzegovina" and states that if

\footnotetext{
29 Radomir Smiljanić, "Srbi neće da finansiraju Tuđmanovu NDH” [The Serbs Will not Finance Tuđman's NDH], Politika (Belgrade), No. 27443, March 2, 1990, p. 13., Željka Križe, Velikosrpska politička propaganda uoči raspada Jugoslavije na primjeru srbijanskoga tiska od donošenja Memoranduma SANU do početka ratnih sukoba u Hrvatskoj (1986. - 1991.), p. 239.
} 
"those good and honest Croats allow Tuđman and his followers to come to power in Croatia then a horrific civil war in Yugoslavia will ensue"..$^{30}$

The readers' letters emboldened the Serbian media in their adversarial attitudes towards Franjo Tuđman because the letters represented the embodiment of the perceptions of the public. Those perceptions were compatible with what the journalists wrote about Franjo Tuđman. It has to be pointed out that the readers were not inhibited by the need to retain even a modicum of objectivity and a semblance of balanced reporting and often went all out and threatened war if the HDZ won the elections.

The push to connect Tuđman with the Ustasha movement continued. On March 4, the Assembly of Vojnić and Vrginmost districts and the Yugoslav Democratic Party organized a rally on Petrova Gora (Petrova Mountain). Nominally the rally was organized as an event supporting the ideal of brotherhood and unity but in reality it was a gathering extolling the ideology of Greater Serbia. The star orator at the rally was the retired general of the Yugoslav Peoples' Army Dušan Pekić. He talked, in general terms, about preserving brotherhood and unity. He averred that many people lived in fear of nationalistic and chauvinistic political parties and demanded that non-communist politicians in Croatia and Slovenia be arrested and pointed out that the legal state still existed and that its organs would put Franjo Tuđman and others under arrest. ${ }^{31}$ The Serbian press gave a lot of attention to the rally but omitted its nationalistic nature and depicted it as a meeting in support of Yugoslavia. ${ }^{32}$ Politika ran, on the front page, the headline "There is No Future without Yugoslavia", with a photograph of a placard on which it was written "Stop all Tuđmans". ${ }^{33}$ The front page in no uncertain terms announced who presented the biggest threat to Yugoslavia. In an article entitled "The Voice of the People against Division and Hatred", it is pointed out that the peoples of the region remember racism and terror and therefore empathize with the plight of the people in Kosovo, which leads them to decidedly reject "the Ustasha movement peddled by Tuđman". The article was accompanied by a text

\footnotetext{
30 Radoslav Blagojević, "Duhovni otac frankovačkih pogroma i ustaškog genocida nad Srbima" [The Spiritual Father of Franciscan Pogroms and Ustasha Genocide Against the Serbs], Odjeci i reagovanja, Politika (Belgrade), No. 27444, March 3, 1990, p. 11. Željka Križe, Velikosrpska politička propaganda uoči raspada Jugoslavije na primjeru srbijanskoga tiska od donošenja Memoranduma SANU do početka ratnih sukoba u Hrvatskoj (1986. - 1991.), p. 239.

31 Ivo Goldstein, Hrvatska 1918. - 2008. [Croatia, 1918 - 2008] (Zagreb: Europapress holding, Novi liber, 2008), p. 659.

32 Željka Križe, Velikosrpska politička propaganda uoči raspada Jugoslavije na primjeru srbijanskoga tiska od donošenja Memoranduma SANU do početka ratnih sukoba u Hrvatskoj (1986. - 1991.), p. 240.
}

33 Politika (Belgrade), No. 27446, March 5, 1990, front page 
in a module - an excerpt from a speech given by the hero of the people Milka Kufrin. She said that "Neo-fascism and Tuđman shall not pass". That was also the headline of the module, printed in bold print and larger font size. ${ }^{34}$

The Serb media kept up their campaign of associating Franjo Tuđman with the Ustasha movement throughout the election campaign in Croatia. One good example of the usual method of the media to portray Tuđman as a warmonger is an interview with Boris Mikelić (a member of the Central Committee of the Communist Party of Yugoslavia and president of the Business board of the Petrinja Gavrilović factory), published in the Nin magazine. The theme of the interview was the position of the Serbs in Croatia and consequences of introducing a multi-party system without prior preparations. Mikelić pointed out that the rally on Petrova Gora was a reaction to the belligerent attitude of some of the Croatian parties, and especially to Franjo Tuđman's truculence. The opinions and attitudes towards Franjo Tuđman of the interviewing reporter are more than obvious from the tenor of the interview. The reporter asked for Mikelićs opinion of the statements made by "Franjo Tuđman and his Gauleiters", according to which they did not wish to provoke a civil war. The usage of the word gauleiter is a clear allusion to the Ustasha regime and the NDH. Mikelić replied that Tuđman wanted civil war and that he had to start one in order to accomplish his objectives. Mikelić also reassured the reporter that Tuđman should not be taken seriously because the Yugoslav Peoples' Army was well capable of defending the regime and the integrity of Yugoslavia. ${ }^{35}$

The Serb media repeatedly accused Franjo Tuđman of conspiring to alter the borders of Bosnia and Herzegovina. In the "Opinions and reactions" section two articles appeared in mid-April authored by Midhat Muradbegović, a retired Yugoslav diplomat. The first article is broader in scope than the second and its title is "Tuđman is Turning Muslims into Islamic Croats". The author draws attention to Tuđman's speech in the Lisinski hall and points out that Tuđman introduced "muslims" (note that the letter " $m$ " is not capitalized) as part of the Croatian nation and stated that the Drina river and the confluence of the Sava and Danube rivers formed the historic and natural borders of Croatia. ${ }^{36}$ It is important to mention that there is nothing remotely similar to the words the author of the article ascribes to Franjo Tuđman in the transcript of

\footnotetext{
34 R. Arsenić, R. Dmitrović, "Glas naroda protiv glasa podele i mržnje” [The Voice of People Against Division and Hatred], Politika (Belgrade), No. 27446, March 5, 1990, p. 5.

35 Svetislav Spasojević, “Gost NIN-a, Borislav Mikelić” [NIN’s Guest, Borislav Mikelić], NIN (Belgrade), No. 2046, March 18, 1990, pp. 12-15.

36 Midhat Muradbegović, “Tuđmanovo pretvaranje Muslimana u "islamske Hrvate” [Tuđman is Turning Muslims into Islamic Croats], Politika (Belgrade), No. 27489, April 17, 1990, p. 15.
} 
his speech published in the HDZ Gazette. ${ }^{37}$ However, in an interview Tuđman gave to the Vjesnik newspaper, he did say that "the Muslims form an integral part of the Croatian nation". Tuđman qualified that statement by saying that the circumstances were such that most Muslims found it more convenient to declare themselves a nation. But, there is nothing in that interview about the border on the Drina river and the confluence of the Sava and Danube rivers. ${ }^{38}$ The second article appeared under the title "Tuđman Steps on the Greater Croatia Bandwagon". The following sentence is highlighted in the introductory paragraph: "The president of the HDZ invites millions of Muslims to participate in a genocide against themselves through voluntary assimilation". The author bases his assertion on the fact that Tuđman stated, in the January 1990 issue of the HDZ Gazette, that, since the national awareness of the $19^{\text {th }}$ century, many Muslims had declared themselves Croats and that the trend was especially popular during the WWII. ${ }^{39}$

It is worth pointing out again that the Serb media put a considerable effort, during the period from the First General Assembly of the HDZ and throughout the election campaign, into depicting Tuđman as a man ideologically connected to the Ustasha regime and the NDH. The key argument used by the detractors of Tuđman was the sentence in which he had characterized the NDH as, amongst other things, an expression of the political desire of the Croatian people for independence. The parts of the speech in which Tuđman mentions AVNOJ and ZAVNOH were deliberately omitted, and the readers were thus exposed only to parts of sentences taken out of their proper context. Various rhetorical means were employed to disqualify Tuđman and depict him as a bad person. The authors of the defaming articles were fond of using neologisms like "Tuđmanovci" (Tuđman's followers) "tuđmanovci brionski" (Tuđman's followers from the Brioni islands), "Tuđmani" (Tuđmans), negative clichés like "apparatchik", and adjectives like "monstrous" and neo-fascistic and similar. The name Tuđman was turned into a noun with absolute negative connotations by which the Serb media identified and discredited the HDZ members and sympathizers.

\footnotetext{
37 "Programske zasade i ciljevi HZD, Uvodno izlaganje dr. Franje Tuđmana", Glasnik Hrvatske demokratske zajednice (Zagreb), No. 8, March, 1990, pp. 17-21.

38 "Imamo najhrvatskiji program - Intervju s dr. Franjom Tuđmanom u Vjesniku od 25. II. 1990 [Our platform is more Croatian than others - Interview with Franjo Tuđman in the February 2, 1990 issue of Vjesnik], Glasnik Hrvatske demokratske zajednice (Zagreb), No. 8, March, 1990, pp. 53-55.

39 Midhat Muradbegović, “Tuđman se uključuje u san o velikoj Hrvatskoj” [Tuđman Steps on the Greater Croatia Bandwagon], Politika (Belgrade), No. 27490, April 18, 1990, p. 19.
} 


\section{HDZ's election victory and constitution of the multi-party assembly}

There were two rounds of voting in the multi-party elections in Croatia on April 22 and 23, 1990, and on May 6 and 7, 1990. The HDZ won a landslide victory with more than $40 \%$ of the votes gained. According to the election law then in place, the HDZ party won about $60 \%$ of the parliamentary seats. ${ }^{40}$

The Serbian press ran pretty detailed reports on the elections and the results but the attention was focused, for the most part, on the electoral results in the predominately Serb areas and the electoral performance of the Serbian Democratic Party. The headlines during the election period were mostly of an informative nature, without comments and analyses. That changed after the first round of voting. The front page of an issue of NIN carried a Croatian flag with the Croatian coat of arms with the headline: "Why is Tuđman Ahead?" In the article the author congratulates the Croatian people on holding the elections and asserts that a HDZ victory has always been in the cards but that only a handful of people expected a landslide victory. ${ }^{41}$

There are no negative connotations associated with Franjo Tuđman in the text. However, the article was accompanied by a photo report and one of the photographs showed a HDZ election poster vandalized by a drawing of a Hitler moustache and hair-do on Tuđman's face. Right next to that photograph was one with Franjo Tuđman among his sympathizers. The caption under both photographs read: "Atmosphere in Zagreb: Tuđman with a recognizable moustache and on Sunday night in Dubrava surrounded by his voters." 42

Politika, on May 13, published an article entitled "We do not Accept Tuđman's Idea of Freedom". The article was a report on the founding assembly of the Belgrade committee of the Serbian Democratic Party from Knin and the headline was a quote by the president of the party Jovan Rašković. According to the article Rašković said that Tuđman was advocating an ethical concept of freedom that was unacceptable to the SDS. Rašković dubbed the HDZ as a Serbo-phobic party but also proclaimed that his hands were extended in a gesture of reconciliation and that Tuđman was free to shake it or spit on it. ${ }^{43}$

\footnotetext{
40 See: Domagoj Knežević, Hrvatska demokratska zajednica od osnivanja do raskida s Jugoslavijom [The HDZ from its formation to the break-up of Yugoslavia] (Zagreb: Hrvatski institut za povijest, 2020), pp. 186-207.

${ }^{41}$ Željka Križe, Velikosrpska politička propaganda uoči raspada Jugoslavije na primjeru srbijanskoga tiska od donošenja Memoranduma SANU do početka ratnih sukoba u Hrvatskoj (1986. - 1991.), p. 251.

42 Milorad Vučelić, “Zašto pobeđuje Tuđman?” [Why is Tuđman Ahead], NIN (Belgrade), No. 2052, April 29, 1990, p. 10.

43 M. PEŠIĆ, "Ne prihvatamo Tuđmanovo stanovište slobode" [We do not Accept Tuđman's Idea of Freedom], Politika (Belgrade), No. 27513, May 13, 1990, p. 6.
} 
During the election campaign the readers of the Serbian press were aquatinted with the skewed depiction of Franjo Tuđman the daily and weekly publications had been carefully fabricating. After the HDZ's election victory, therefore, the Serbian press did not lavish too much attention on Tuđman. The press media shifted its attention back on Tuđman following the violent clashes between the football fans during the Dinamo - Crvena Zvezda football game on May 13, 1990. ${ }^{44}$ The Serbian media, with the exception of a few NIN reporters, blamed the Croatian side for the clashes. In one article published in Politika, Franjo Tuđman was described as the main culprit behind the incident. The author of the article concludes, on the basis of the fact that the HDZ, following the incident, requested that the Executive Committee of the Assembly replace all those responsible in the Zagreb Secretariat of Internal Affairs and the Republic Secretariat of Internal Affairs, that the incident was staged for the purpose of provoking purges in the police force. The author fortifies his theory by stating that Tuđman, in his speeches during the election campaign, said that the number of Serbs in the security organs of the state was unacceptably high. Connecting the dots still further, the author states that Tuđman is experienced in manipulating the game of football for political purposes and points out that the supporters of the FC Partizan still remember, with acrimony and after 30 years, that it was Franjo Tuđman who, as the president of FC Partizan, changed the colors and design of the Partizan FC football uniform from red and white to black and white. According to the author, Tuđman manipulated the supporters of FC Dinamo into collectively joining the HDZ party by giving them money, gave an amount of money to FC Dinamo for promoting the HDZ party and showed up at the game protected by bodyguards and basked in the applause of 50,000 supporters. As proof the author claims that FC Dinamo supporters displayed banners featuring slogans of support for the HDZ party. The author rounds up the theories by stating that Tuđman

\footnotetext{
44 A large group of Crvena Zvezda supporters arrived in Zagreb before the Dinamo - Crvena Zvezda football game. During the morning these supporters vandalized businesses and attacked passersby in Zagreb. The police did not react. At the game itself they occupied the South Stand. There were a handful of Dinamo supporters there and the Crvena Zvezda supporters attacked them and grievously injured a number of them. When they had cleared the South Stand of the Dinamo supporters, they proceeded to destroy the seats. The police did not react. The Dinamo supporters, occupying the North Stand, burst onto the pitch and rushed towards the South Stand. At that point the police reacted and attacked the Dinamo supporters with batons and water cannons. Ivo Goldstein, Hrvatska 1918. - 2008., pp. 661-662; Kronologija rata: Agresija na Hrvatsku i Bosnu i Hercegovinu (s naglaskom na stradanja Hrvata u BiH), [Chronology of the War, Agression against Croatia and Bosnia and Herzegovina (with emphasis on the plight of Croats in $\mathrm{BiH}$ ] ed. Miroslav Krmpotić (Zagreb: Hrvatski informativni centar; Slovo, 1998), p. 23.
} 
has realized a long time ago that the game of politic is better played at football stadiums than at political meetings, congress halls, union halls etc. ${ }^{45}$

The incident at the game was used by the Serbian media as another piece of evidence proving that the Serbs in Croatia were in a grave and immediate danger from the soon-to-be-formed government. Immediately prior to the constituting session of the Croatian Assembly the Serbian press focused of the Serbian Democratic Party's refusal to participate in the Assembly due to the situation created by the "Mlinar case". Miroslav Mlinar, 23 years old, the president of the Benkovac branch of the Serbian Democratic Party was found wounded. Croats were blamed for the attack on him, but it was soon proven that the attack was staged. ${ }^{46}$

The constituting session of the multi-party Assembly of the Socialist Republic of Croatia was held on May 30, 1990. At the session Franjo Tuđman was elected the president of the Presidency of the Socialist Republic of Croatia. ${ }^{47}$ Večernje novosti ran detailed reports on the progress of the Statehood Day celebrations in Zagreb without delving too deeply into political issues. In an article entitled "A Ducat for a New Croatia" all aspects of the celebration were described in minute detail, including Ante Vrdoljak's requesting of Franjo Tuđman to, according to an old Croatian custom of giving presents to newly born children, lay a feather and a ducat into a cradle symbolizing the birth of Croatia. ${ }^{48}$

Politika informed its readership, on the front page, that Tuđman had been elected as the president of the Presidency. A photograph of Tuđman accompanied the headline..$^{49} \mathrm{~A}$ feature article about the constituting session was entitled: "The Assembly without the Serbian Democratic Party". The constituting session was not the only theme featured in the issue. The course of the session was followed through a series of texts under various subheadings. Parts of some speeches were printed in bold font. The most attention was given to Franjo Tuđman's speech. The readers were informed that Tuđman had spoken about the history of the Croatian people in the contexts of nationhood, cul-

\footnotetext{
45 Stevan Zec, "Maksimirska vatra mržnje" [The Maksimir Fire of Hatred], Politika (Belgrade), No. 29515, May 15, 1990, p. 11. Željka Križe, Velikosrpska politička propaganda uoči raspada Jugoslavije na primjeru srbijanskoga tiska od donošenja Memoranduma SANU do početka ratnih sukoba u Hrvatskoj (1986. - 1991.), p. 257.

46 Ante NAZOR, Velikosrpska agresija na Hrvatsku 1990-ih/ Greater Serbian Aggression on Croatia in the 90's, (Zagreb, 2011), p. 32.

47 Ante Nazor, Velikosrpska agresija na Hrvatsku, p. 32.

48 "Dukat za novu Hrvatsku" [A Ducat for a New Croatia] Večernje novosti (Belgrade), No. 23865, May 31, 1990, p. 7.

49 Politika (Belgrade), front page, No. 27531, May 31, 1990
} 
ture and politics. Politika quoted a part of the speech dealing with the NDH and the People's Liberation War in which Tudman, having referred to that era as "occupation" and "revolution", characterizations in keeping with the official discourse, said that the Croatian Assembly was restored in Pavelićs independent Croatia, a polity that shared the faith of the Axis powers and Hitler's European order, which could not fulfill the role of the carrier and protector of the Croatian state sovereignty. That historical role, according to Franjo Tuđman, was assumed by the $\mathrm{ZAVNOH}$ as a revolutionary assembly through the establishment of the Federative state of Croatia within the framework of the AVNOJ principles about the right of every people, including the Croatian people, to self-determination to secession. The author of the article points out that Tuđman emphasized that the first and most important task of the newly formed democratic government was to establish the spiritual, material and legal conditions for creating a legal, civil and national sovereignty in the context of all citizens so as to foster a sense of cooperativeness and trust in society. Under separate subheadings the author emphasizes Tuđman's statements that initiatives for revenge will not be allowed in Croatia and that he will advocate the confederate option. The article ends with a quote by Tuđman: "Long live the democratic and sovereign Croatia." ${ }^{50}$

The author refrained from criticizing Tuđman and making remarks. It is interesting to note that he quoted, unlike his colleagues reporting on the Lisinski event, the part of Tuđman's speech about the People's Liberation War and ZAVNOH. One of the contributors (Ratko Dmitrović) penned the article entitled "A Metamorphosis of a General", published in NIN, in the issue devoted to the Assembly in the Lisinski hall. Dmitrović, in that article, wrote with a hefty dose of criticism and sarcasm about Franjo Tuđman.

Dmitrović penned, and NIN published, an article about the constitutive session entitled “'The Liberation Day"” (note the quotation marks). The subtitle read: "Only God and no one else can supervise the Assembly!" The article was accompanied by photographs of the proceedings in the hall and Zagreb cathedral with the caption: May 30, Anno domini 1990, Zagreb: in the cathedral and in the hall. Unlike his peers in relation to the articles published in Politika and Večernje novosti, Dmitrović chose not to pull any punches and excoriated Tuđman and Croatian citizens. In the article he accuses Croatian citizens of harboring Nazi sympathies and being lukewarm toward the Anti-fascist movement. In the introductory paragraph the author claims that he doesn't know with what degree of enthusiasm the citizens of Zagreb greeted the liberation in 1945, but that the level of ecstasy of the citizenry upon the

50 Radoje Arsenić, Ratko Dmitrović, "Sabor bez Srpske demokratske stranke" [The Assembly without the Serbian Democratic Party], Politika (Belgrade), No. 27531, May 31, 1990, p. 9. 
"liberation of Croatia from Communist yoke and other tortures" was astonishingly high. Dmitrović could not resist reporting that some eyewitnesses had said that the pitch of the ardor was higher than when the German units had marched into Zagreb over flowers and Gavrilović sausages. ${ }^{51}$ The article is suffused with attempts at sarcasm. Dmitrović reports that more former Communists than "born believers" attended the Mass for "the new and sovereign Croatia" and that the bunch was led by Tuđman and Josip Manolić. The author's description of the atmosphere in front of the hall during the session centers on scenes showing fervent HDZ members signing old Croatian songs but also some new songs with rhymes like: "Franjo, the name divine, Franjo the dream sublime". A note of disdain towards his subject matter, is obvious in the author's statement that Stipe Šuvar and Ante Marković, as expected, did not attend the session but that the HDZ expected their brethren the Slovenes to be there but, alas, they were not. Dmitrović then reverts to sarcasm again and claims that on May 30 Tuđman was very worried: "From the moment he donned the presidential sash and showing up at Republic Square, he looked as if he had seen the Mother of God". The author further claims that Tuđman did not react to shouts from the crowd "Croatia is free!" and walked down Radić Street between two rows of spectators in a somber, worried mood, "downcast, without a shred of optimism in his demeanor". "Obviously, he has realized that the cross of responsibility taken through the results of the plebiscite and the Croatian people's desire for a sovereign and independent Croatia is going to be too difficult to bear", the author concludes. ${ }^{52}$

The difference in tone in Dmitrovićs articles written about the same subject, for Politika and NIN, is obvious, not to say startling. Of course, editorial policies played a role with regards to the differences, despite the fact that both publications belonged to the same publishing house. This does not mean that Politika thawed its attitude to the HDZ, Tuđman and the Croatian people. The reports Politika ran about the incident at the Dinamo - Crvena Zvezda game testify to that. Still, the reports Politika and Večernje novosti ran about the election results and the first session were more objective and more professional than those published by NIN. It could be argued that Politika, in the period in question, focused more on the Serbian Democratic Party and the position of Serbs in Croatia and wanted to acquaint its readership with their activities and plans.

51 Ratko Dmitrović, "Dan oslobođenja” [The Liberation Day], NIN (Belgrade), No. 2057, June 3, 1990, p. 13.

52 Ratko Dmitrović, “Dan oslobođenja”, NIN (Belgrade), No. 2057, June 3, 1990, p. 14. 


\section{Franjo Tuđman in Serbian press in the lead-up to the Serb rebellion in Croatia}

After the elections the Serbs in Croatia became the main topic in the Serbian press. All gatherings, rallies and activities were written about in minute detail. The propaganda campaign against Croatia gathered pace leading up to the adopting of new amendments to the Croatian Constitution. Politika took the lead in fostering national intolerance and hatred towards the Croatian people. The headlines proclaimed that the Serbs in Croatia were endangered but unified in their determination to fight for their rights. ${ }^{53}$ The representatives of the Serb community in Croatia and the Serbian media outlets were worried that the new amendments would revoke the Serbs' status of a constituent nation in Croatia and reduce them to a national minority. Sometimes the articles about the position of the Serbs in Croatia served as a smoke screen for smuggling in articles about Tuđman. One such article was entitled "Is Tuđman Getting Rid of His Hawks?” The author of the article points out that the HDZ is trying to defuse the situation, but also expresses his suspicion that the Serbs in Croatia are being reduced to an ethnic minority. He concludes that Tuđman does not believe that Yugoslavia is a proper state and advocates the creation of a confederacy as a contractual union of sovereign states.

The author accuses Tuđman of ignoring the question of whether the Serbs in Croatia will be treated as an ethnic minority and treating the issue as not significant while it is clear that the issue presents a serious problem Tuđman should have a clear opinion on. As proof of his conclusion the author states that Tuđman, in his first speech in the Assembly as the President of the Presidency of Socialist Republic of Croatia he did not mention the issue of inter-national relations in Croatia under the new government. This line of thinking directly leads the author to assert that the situation in the Assembly is without precedent and that appropriate conclusions should be drawn from that fact. ${ }^{54}$

Quite a few articles about Tuđman slipped through the cracks of the overall theme of the situation of the Serbs in Croatia. He was criticized for his opinions and attitude towards Bosnia and Herzegovina. In the "Opinions and reactions" section a letter written by Milić od Mačve ${ }^{55}$ was published. The letter was entitled "Tuđman does not Know his History". The subtitle read: "What other Explanation for his Drawing of Bosnian Borders and his Opinion on

\footnotetext{
53 v. Željka Križe, Velikosrpska politička propaganda uoči raspada Jugoslavije na primjeru srbijanskoga tiska od donošenja Memoranduma SANU do početka ratnih sukoba u Hrvatskoj (1986. - 1991), pp. 263-265.

54 Radivoje Arsenić, “Oslobađa li se Tuđman svojih jastrebova” [Is Tuđman Getting Rid of His Hawks?], Politika (Belgrade), No. 27534, June 3, 1990, pp. 11-12.

55 The real name of the artist is Milić Stanković.
} 
Bosnia". The tenor of the letter is ultra-Serb nationalist. Milić accuses Tuđman and the HDZ of planning to convert the Muslims in Bosnia and Herzegovina using all violent and non-violent means at their disposal and claims that the $\mathrm{HDZ}$ is the natural successor the NDH. "Today, when the trend in Europe is towards unity and free travel, the supporters of Tuđman seek to steal from us Bosnia and Herzegovina and our proud Dalmatia with the famous Republic of Ragusa so as to create a religious and linguistic conflict", ${ }^{56}$ Milić writes. He elaborates at length why, according to him, Bosnia and Herzegovina does not belong to Croatia and explains that he has no problem with the concept of redrawing the borders but that not everyone has the right to do that.

One day later another letter was published in the same section. It was entitled "Laying Claim to Bosnia and Herzegovina is a Folly". The author criticizes both Franjo Tuđman and Vuk Drašković and makes his position clear in the subtitle: "We Are Sending a Message to Tuđman and Drašković. We Tell Them to Learn the History of Bosnia". Milić asserts that Tuđman revealed his true nature after the elections to the Yugoslav and world public and expresses his disappointment with the fact that the majority of the Croats voted for a party whose leader openly claims allegiance to the NDH. In the concluding paragraph Milić warns that 'some people', informed by their "nationalistic lust" have forgotten that 19 nations and ethnicities live in Yugoslavia and that they are entitled to freedom. He ends the harangue by saying that Tuđman calls the Muslims "Croatian Muslims" just like Ante Pavelić did. ${ }^{57}$

In mid-June 1990, Politika introduced anther section called "Open phone lines for discussing the issue of the Serbs in Croatia". Readers could now call the editorial office by phone and ask questions to be posed later by the editors to the guests invited to the office. The editors explained that the section had been introduced because the Yugoslav public had been interested, for some time, in the position of the Serbs in Croatia, and especially after the multi-party elections and the HDZ's victory "following which brutal attacks, pressures and threats against Serbs intensified dramatically". ${ }^{8}$ The first guest

\footnotetext{
56 Milić od Mačve, “Tuđman ne zna istoriju” [Tuđman Does not Know his history], Politika (Belgrade), No. 27534, June 3, 13.

57 Aladin Veledar, "Svojatanje Bosne je nerazuman akt" [Laying Claim to Bosnia and Herzegovina is a Folly], Politika (Belgrade), No. 27535, June 4, p. 13.

58 Radivoje Petrović, Branislav Radivojša, “Otvoreni telefon Politike o Srbima u Hrvatskoj, Borićemo se do kraja za suverenost srpskog nacionalnog bića u Hrvatskoj” [Open phone lines for discussing the issue of the Serbs in Croatia: We Shall Fight to the End for the Sovereignty of the Serb National Entity in Croatia], Politika (Belgrade), No. 27594, June 18, 1990, pp. 7-8., v. Željka Križe, Velikosrpska politička propaganda uoči raspada Jugoslavije na primjeru srbijanskoga tiska od donošenja Memoranduma SANU do početka ratnih sukoba u Hrvatskoj (1986. - 1991), pp. 263-265.
} 
was Jovan Rašković. The interview was entitled after this sentence by Rašković: "We shall fight to the end for the sovereignty of the Serb national entity in Croatia." According to the editors, the most interest garnered the question (among many questions from readers from all over Yugoslavia, but mostly from Croatia) of a reader from Prizren who asked how the Serbs in Croatia intended to defend their lives and property if threatened by "extremists among Tuđman’s supporters”. Rašković replied that democratic pressures would be answered with democratic means, but if the property and physical integrity of the Serb entity in Croatia came under threat then the only option would be to fight fire with fire. The title "SKH Opens Door for Tuđman" was highlighted in the text of the interview. ${ }^{59}$

Tuđman was also accused, in an article by the same author who accused him of organizing the incident at the Dinamo - Crvena Zvezda football game, of being the mastermind behind the strike in the Vukovar Borovo factory. The article was entitled "Tuđman Pulls the Strings behind the Strike". The author does not show the direct link between Tuđman and the striking workers. He does, however, claim that the local branch of the HDZ has been colluding with the workers for the ultimate purpose of getting rid of the Serbs among the Borovo work force. ${ }^{60}$ Despite the author's inability to prove Tuđman's involvement in the strike the headline itself was sufficient to stir the hearts of most of the readers.

On July 25, 1990, the Croatian parliament passed the amendments to the Constitution by which the adjective "socialist" was dropped from the name of the republic and the historic Croatian checkerboard coat of arms replaced the red star in the Croatian flag. The Latin script became the official script but the usage of the Cyrillic script was guaranteed and protected in the predominately Serb areas. ${ }^{61}$

On the same day a Serb Assembly was held in the town of Srb. There was only one item on the agenda - the constitutional position of the Serbs in Croatia. The Assembly occasioned the founding of the Serbian National Council, composed mostly of officials of the Serbia Democratic Party. Then, in front of a huge gathering comprising 120,000 people, the Declaration of the Sovereignty and Autonomy of the Serb People was passed. The Declaration asserted

\footnotetext{
59 Radivoje Petrović, Branislav Radivojša, "Borićemo se do kraja za suverenost srpskog nacionalnog bića u Hrvatskoj”, Politika (Belgrade), No. 2759, June 18, 1990, pp. 7-8.

60 Stevan Zec, "Iza štrajka stoji Tuđman“[Tuđman Pulls the Strings Behind the Strike], Politika (Belgrade), No. 27554, June 23, 1990, p. 9.

61 "Odluka o proglašenju Amandmana LXIV. do LXXV. na Ustav Socijalističke Republike Hrvatske" [The Decision on Passing Amendments LXIV to LXXV to the Constitution of Socialist Republic of Croatia], Narodne novine, No. 31/90, June 28, 1990.
} 
the right to self-determination and the right to secession and proclaimed the sovereignty of the Serb people in Croatia and the right to autonomy. Furthermore, on the strength of the Declaration, all constitutional and other legal changes which negate the sovereignty of the Serbs as a people and minimize their rights for autonomy were declared nil and void. On July 31, also in Srb, the constituting session of the Serbian National Council was held. The Serbian National Council rejected the amendments to the Croatian Constitution and reached a decision of organizing a referendum on autonomy of the Serb people in Croatia which would be held on August 19 and $20 .{ }^{62}$

The Serbian press reported in detail about these events. The article in Politika describing the events in Srb included excerpts from Jovan Rašković speech. It is important to mention that the speech was often interrupted by cheers in support of a greater Serbian state and "We'll butcher Tuđman". ${ }^{63}$ The latter type of cheers was omitted in the article. But, the part of the Raškovićs speech about Tuđman was printed in bold letters. "Mister Tuđman is attacking me, but I don't want to attack anyone, not even Mister Tuđman. For what it is worth, it seems to me that Mister Tudman would like to set up a modern and democratic Croatia in which the Serbs would be equal but he is constrained and impotent. I will continue to talk with Mister Tuđman, but I will not talk to those HDZ members who are infected with the Ustasha bug." ${ }^{\prime 64}$ In this way the author emphasized the conciliatory and rational attitude of Rašković towards Tuđman. The implication was that the responsibility for a future conflict rested on Tuđman's shoulders.

The Croatian government declared the announced referendum on Serb autonomy in Croatia illegal because it ran against the provisions of the 1974 Constitution of the Socialist Republic of Croatia ${ }^{65}$ As the date of the holding

\footnotetext{
62 Republika Hrvatska i Domovinski rat 1990. - 1995.: Dokumenti institucija pobunjenih Srba u Republici Hrvatskoj (1990. - 1991.) [The Republic of Croatia and the Croatian War of Independence 1990-1995, Documents of the Rebel Serbs in the Republic of Croatia], ed. Mate Rupić (Zagreb: HMDCDR, 2007), "Zapisnik osnivačkog zasjedanja Srpskog sabora u Srbu" [Transcript from the Constitutive Session of The Serb Assembly in Srb], p. 39., Nikica Barić, "Srpska pobuna u Hrvatskoj 1990. - 1995." [The Serb Rebellion in Croatia 1990-1995], in: Stvaranje hrvatske države i Domovinski rat [Creation of the Croatian State and the Croatian War of Independence] (Zagreb: Školska knjiga, 2006), pp. 204-206; Ozren Žunec, Goli život I: Socijetalne dimenzije pobune Srba u Hrvatskoj, [Survival and Social Dimensions of the Serb Rebellion in Croatia] (Zagreb: Demetra, 2007) p. 264.

63 Kronologija rata: Agresija na Hrvatsku i Bosnu i Hercegovinu (s naglaskom na stradanja Hrvata u BiH), ed. Miroslav Krmpotić, p. 26.

64 Milan Četnik, Radovan Kovačević, "Proglašena autonomija Srba u Hrvatskoj”, [Serb Autonomy in Croatia Declared] Politika (Belgrade), No. 27587, June 26, 1990, p. 7.

65 See: Ante Nazor, Velikosrpska agresija na Hrvatsku 1990-ih, p. 38.
} 
of the referendum drew near the Serbian media stepped up their efforts to convince the public that the Serbs in Croatia were in grave peril. Most articles were spiced up with stories about crimes committed against the Serbs in the NDH during WWII. The editorial strategy was clear. The intention was to traumatize the readership into believing that the Croatian government intended to launch a campaign of genocide against the Serbs in Croatia. The tone of fear mongering in the articles increased steadily and reached fever pitch immediately prior to the Serb rebellion in Croatia. ${ }^{66}$

For example, NIN ran, at the end of June, an article entitled "The Ninth Circle of Hell" which featured descriptions, in clinical detail, of killing of Serbs, including Orthodox priests. A number of photographs accompanied the article. ${ }^{67}$ Throughout June Večernje novosti published installments of Milovan Čelebić's story entitled "The Roots of Hatred and Genocide against the Serbs". ${ }^{68}$

Politika was at the forefront of this political campaign. Its editorial office even took part in a speleological endeavor. The subject of exploration was the Šaranova Jama (Carp's Pit) into which, according to Politika, Ustasha soldiers had thrown the victims they had killed in the Jadovno camp. ${ }^{69}$ A series of articles was published about that, with detailed descriptions of the cruelty of the Ustasha soldiers and sufferings of the victims. Invariably, the authors put those horrors into the contemporary context, thus linking the NDH regime with the HDZ government. In one such article the author, having related the account of "the Ustasha butcher Jose Orešković", according to which Orešković, at Maks Luburić's instigation, killed a child by squashing the child's head with his foot, switches focus to the present and asks himself why there are people now, 50 years later, who wish that monstrosity to continue. He himself provides the answer and claims that such people exists because new intellectuals, of the Doctor Mile Budak type, working in the inner circle of the HDZ, incite hatred and paranoia against the Serbian people. The article ends with the assertion that the butcher school is easily graduated from. ${ }^{70}$ In the last ar-

\footnotetext{
66 See: Željka Križe, Velikosrpska politička propaganda uoči raspada Jugoslavije na primjeru srbijanskoga tiska od donošenja Memoranduma SANU do početka ratnih sukoba u Hrvatskoj (1986. - 1991), pp. 274-283.

67 Milo Gligorijević, “Deveti krug pakla” [Ninth Circle of Hell], NIN (Belgrade), No. 2061, June 29, 1990, pp. 50-53.

68 Milovan Čelebić, "Koreni mržnje i genocida nad Srbima” [The Roots of Hatred and Genocide Against the Serbs], Večernje novosti (Belgrade), June, 1990.

69 Branko Đurica, “Ubijanje vršeno na više načina”, [Many Methods of Murder] Politika (Belgrade), No. 27587, June 26, 1990, p. 13.

70 Branko Đurica, "Srpski opanak na dnu jame" [A Serb Shoe at the Bottom of the Pit], Politika (Belgrade), No. 27591, June 30, 1990, p. 9.
} 
ticle of the series on the Jadovno camp the author sharply condemns Tuđman, explains how the Serbs in Croatia are in great peril, claims that "some Croatian guard" is in the process of being formed in Croatia, a force that is undoubtedly going to be given the task of pacifying the population of the Community of north-Dalmatian and Lika municipalities. "In addition to all of that," the author points out, "Doctor Franjo Tuđman, who styled himself a historian before he became the father of the Croatian nation, stated that Jews had not been persecuted in the NDH." The article ends with the author's statement that, having read Tuđman's "scholarly opinion" about how only 50,000 Serbs were killed in the Jasenovac camp, nothing could surprise him anymore. ${ }^{71}$

Even after the beginning of the Serb rebellion in Croatia (August 17, 1990), the Serbian press continued its campaign of defaming the Croatian government and Franjo Tuđman. Quite a few people in Serbia accepted the Serbian media's portrayal of Franjo Tuđman at face value. The slogans voiced and displayed at a rally in Stara Pazova organized by the Serbian Renewal Movement in support of the Serbs in Croatia proves the point. Večernje novosti ran an article about the rally entitled "Determined to Defend Themselves". A few thousand people, from Nova Pazova, Stara Pazova, Vršac and other places, attended the rally. The slogans that had been shouted at the rally were printed in a module accompanying the article. "Croats and Tuđman should be aware that the Serbs are ready for warfare!" and "Tuđman, you son of a bitch!" were two of the many similar slogans. ${ }^{72}$

The Serbian media continued to run stories about attacks on Serb civilians in Croatia and how many Serbs fled the country because they were afraid of the new government. Journalists from Serbia ostensibly interviewed a number of Croatian Serbs and these interviews were published. If the interviews are genuine, the only logical conclusion is that the Serbs in question, and many others, fell under the spell of the propaganda campaign launched by the Serbian media to discredit Franjo Tuđman and Croatian government and spread fear. ${ }^{73}$ Politika ran, in September, an article under the heading "Sad Autumn

71 Branko Đurica, "U krvavim orgijama učestvovali su i katolički sveštenici" [Catholic Priests Participated in Orgies of Violence], Politika (Belgrade), No. 27592, June 31, 1990, p. 9.

72 B. B. Mijić, "Odlučni da se brane", [Determined to Defend Themselves] Večernje novosti (Belgrade), No. 23944, August 18, 1990, p. 4.

73 Politika was popular with the Serbs in Croatia. In one document issued in 1992 in Glina Municipality it is stated that the publications printed by the Politika publishing house were the most popular. It is pointed out in the same document that more than 400 copies of Expres politika and more than 100 copies of Politika were sold in one day; Nikica Barić, Srpska pobuna u Hrvatskoj, p. 50; The fact that many local people in Knin invited the Politika journalists who reported on the celebrations of the Kosovo battle in Knin into their homes testifies to how popular Politika was among the local population. Workers of the Knin post office sent a letter 
in Vinkovci for the Vojvodić Family". The article was entitled "Fleeing from Cruelty". The article describes how the relations between the Serbs and Croats in the villages in the environs of Vinkovci and Vukovar worsened. The author cites the case of Professor Milan Vojvodić who was allegedly attacked and almost stabbed to death in a pub by "young HDZ hawks" simply because his beard resembled that of Vuk Drašković. One section of the article was entitled "Tuđman is coming, the Vojvodići are leaving". The author quotes the wife of Milan Vojvodić who allegedly said: "Tomorrow, Tuđman will come here, but tonight we are leaving... Maybe for good. We don't want to witness tomorrow's festivities of the HDZ people and their masters". ${ }^{74}$

This last example aptly illustrates the level of the Serbian media's campaign against the HDZ and Franjo Tuđman. Many Serbs, contrary to common sense and evidence, believed that the HDZ and Franjo Tuđman were bent on doing them harm and were afraid of the new Croatian government.

\section{Conclusion}

The Serbian media, from the get-go, portrayed Franjo Tuđman as a Croatian nationalist connected to former political movements which were viewed in a negative light by the public in Serbia and other Yugoslav republics. Tuđman, in a softer variant of derogatory portrayals, was linked to the 1971 Croatian Spring movement. But, the Serbian media went all out by linking Franjo Tuđman with the Ustasha movement and the NDH regime. The belief, fostered by fear-mongering articles, of the Serbian public that Franjo Tuđman embodied, somehow, the continuation of the NDH regime automatically disqualified him as a politician and put him in the category of an enemy of the Serbian people. The theme of Franjo Tuđman being a Fascist was supported in many articles by citing his research according to which far less people were killed in the Jasenovac camp than the official, Communist narrative had suggested. The authors of the articles had a field day with the fact that Tuđman was a former Communist and a Partisan general, describing him as a person without true ideals and nothing more than an opportunist.

The Serbian media based its claims that Tuđman was an Ustasha sympathizer bent on resurrecting the $\mathrm{NDH}$ on his statement, given during his

\footnotetext{
of support to Politika; Željka Križe, Velikosrpska politička propaganda uoči raspada Jugoslavije na primjeru srbijanskoga tiska od donošenja Memoranduma SANU do početka ratnih sukoba u Hrvatskoj (1986. - 1991), p. 198.

74 Branislav Đurica, Nikola Vidić, "U bekstvo od svireposti” [Fleeing from Cruelty], Politika (Belgrade), No. 27631, September 8, 1990, p. 13.
} 
speech in the Lisinski concert hall, that the NDH had represented the desire of the Croatian people for independence. The statement was always cited out of the context within which it had been given and it was often misquoted.

The authors of the articles used various rhetoric means and labels to describe Tuđman and the HDZ. The strategy was calibrated to incite the public to hate Tuđman, or, at least, form a negative opinion of him. The authors often used Tuđman's name to coin new derogatory words and expressions for the members of the HDZ and Tuđman's sympathizers. Tuđman was accused of various things. For example, he was accused of staging the incident at the Dinamo - Crvena Zvezda football game, of destroying Yugoslavia, of trying to divide Bosnia and Herzegovina, of trying to turn Muslims into Croats and of organizing a strike. Franjo Tuđman was gradually turned into a symbol of everything negative associated with the new Croatian government. His name, and the HDZ, were mentioned, in a series of articles, in connection to the brutal crimes of the Ustasha regime, published before the Serb rebellion in Croatia. The purpose of these articles was to make the Serbian public psychotic and afraid of the Croatian government and the Croatian people. The media campaign against Franjo Tuđman was just one cog in the wheel, albeit an important one, in the propaganda machine espousing the ideology of Greater Serbia. That propaganda machine was put into motion in mid-1989, before the start of the media campaign against Tuđman and the HDZ. It is safe to assert that the HDZ's victory in the elections provided the Greater Serbian propaganda machine with a flywheel which, in turn, created an irreversible momentum.

\section{Bibliography}

Arsenić, R. Dmitrović. "Glas naroda protiv glasa podele i mržnje" [The Voice of People Against Division and Hatred], Politika (Belgrade), No. 27446., March 5, 1990, p. 5.

Arsenić, Radivoje. "Na poznatoj platformi 'maspoka" [The Familiar Maspok Platform], Politika (Belgrade), No. 27084, March 2, 1989, p. 20.

Arsenić, Radivoje. "Oslobađa li se Tuđman svojih jastrebova” [Is Tuđman Getting Rid of his Hawks?], Politika (Belgrade), No. 27534, June 3, 1990, pp. 11-12.

Arsenić, Radivoje, Dmitrović, Ratko. "Sabor bez Srpske demokratske stranke" [The Assembly without the Serbian Democratic Party], Politika, No. 27531, May 31, 1990, p. 9.

Barić, Nikica. "Srpska pobuna u Hrvatskoj 1990. - 1995." [The Serb Rebellion in Croatia 1990-1995], in: Stvaranje hrvatske države i Domovinski rat 
[Creation of the Croatian State and the Croatian War of Independence]. (Zagreb: Školska knjiga, 2006.)

Barić, Nikica. Srpska pobuna u Hrvatskoj, 1990. - 1995. [The Serb Rebellion in Croatia 1990-1995]. (Zagreb: Golden marketing - Tehnička knjiga, 2005.)

Blagojević, Radoslav. "Duhovni otac frankovačkih pogroma i ustaškog genocida nad Srbima" [The Spiritual Father of Franciscan Pogroms and Ustasha Genocide Against the Serbs], "Odjeci i reagovanja", Politika (Belgrade), No. 27444., March 3, 1990, p. 11.

Čelebić, Milovan. "Koreni mržnje i genocida nad Srbima" [The Roots of Hatred and Genocide Against the Serbs], Večernje novosti (Belgrade), June, 1990.

Četnik Milan, Kovačević, Radovan. "Proglašena autonomija Srba u Hrvatskoj" [Serb Autonomy in Croatia Declared], Politika (Belgrade), No. 27587, June 26, 1990, p. 7.

"Diskretni okus Endehazije" [Discreet Taste of the NDH Regime], Večernje novosti, No. 23722, February 25, 1990., front page.

Dmitrović, Ratko. "Dan oslobođenja" [The Liberation Day], NIN, No. 2057, June 3, 1990, pp. 13-14.

Dmitrović, Ratko. "Metamorfoza jednog generala" [A Metamorphosis of a General], NIN (Belgrade), No. 2044 March 4, 1990, pp. 10-11.

"Dukat za novu Hrvatsku" [A Ducat for a New Croatia], Večernje novosti (Belgrade), No. 23865, May 31, 1990, p. 7.

Đurica, Branislav, Vidić, Nikola. "U bekstvo od svireposti” [Fleeing from Cruelty], Politika (Belgrade), No. 27631, September 8, 1990, p. 13.

Đurica, Branko. "Srpski opanak na dnu jame" [A Serb Shoe at the Bottom of the Pit], Politika (Belgrade), No. 27591, June 30, 1990, p. 9

Đurica, Branko. "U krvavim orgijama učestvovali su i katolički sveštenici" [Catholic Priests Participated in Orgies of Violence], Politika (Belgrade), No. 27592, June 31, 1990, p. 9.

Đurica, Branko. "Ubijanje vršeno na više načina" [Many Methods of Murder], Politika, No. 27587, June 26, 1990, p. 13.

Gligorijević, Milo. "Deveti krug pakla” [Ninth Circle of Hell], NIN (Belgrade), No. 2061, June 29, 1990, pp. 50-53.

Gluščević, D. "Opet Bog i Hrvati” [God and Croats Again], Večernje novosti (Belgrade), No. 23723, February 26, 1990, p. 4.

Glušćević, D. "Diskretni okus Endehazije” [Discreet Taste of the NDH Regime], Večernje novosti (Belgrade), No. 23722, February 25, 1990, p. 9. 
Goldstein, Ivo. Hrvatska 1918. - 2008 [Croatia, 1918 - 2008]. (Zagreb: Europapress holding, Novi liber, 2008.)

Gredelj, Stjepan. "Mediji, populizam i govor mržnje” [Media, Populism and Hate Speech], in: Okrugli sto, Odjeci i reagovanja (Beograd, 2001)

Ignja, Petar. "Vampiri maspoka" [Maspok Vampires], NIN (Belgrade), No. 1993, March 5, 1989, p. 12.

"Imamo najhrvatskiji program - Intervju s dr. Franjom Tuđmanom u Vjesniku od 25. II. 1990" [Our platform is more Croatian than others - Interview with Franjo Tuđman in the February 21990 issue of Vjesnik], Glasnik Hrvatske demokratske zajednice (Zagreb), No. 8, March, 1990, pp. 53-55.

Kerbler, Jurica. "Poziv na rušenje Jugoslavije” [An Appeal for Destroying Yugoslavia], Večernje novosti (Belgrade), No. 23402, March 1, 1989, p. 15

Knežević, Domagoj. Hrvatska demokratska zajednica od osnivanja do raskida s Jugoslavijom [The HDZ from its Formation to the Break-up of Yugoslavia]. Zagreb: Hrvatski institut za povijest, 2020.

Knežević, Vesna. "Tako je bilo u Lisinskom" [That's how it was in the Lisinski Hall], NIN (Belgrade), No. 2044, March 4, 1990, pp. 10-11.

Križe, Željka. Velikosrpska politička propaganda uoči raspada Jugoslavije na primjeru srbijanskoga tiska od donošenja Memoranduma SANU do početka ratnih sukoba u Hrvatskoj (1986. - 1991.) [Greater Serbian Political Propaganda on the Eve of the Disintegration of Yugoslavia from the SANU Memorandum to the Beginning of the War Conflict in Croatia (1986-1991)], PhD thesis. Zagreb: University of Zagreb, Faculty of Croatian Studies, 2015), URL: https://urn.nsk.hr/urn:nbn:hr:111:907689.

Kronologija rata: Agresija na Hrvatsku i Bosnu i Hercegovinu (s naglaskom na stradanja Hrvata $u$ BiH) [Chronology of the War, Agression against Croatia and Bosnia and Herzegovina (with emphasis on the plight of Croats in $\mathrm{BiH}$ ], ed. Miroslav Krmpotić. Zagreb: Hrvatski informativni centar; Slovo, 1998.

M. Pešić. "Ne prihvatamo Tuđmanovo stanovište slobode” [We do not Accept Tuđman's idea of freedom], Politika (Belgrade), No. 27513, May 13, 1990, p. 6.

Mijić, B. B. "Odlučni da se brane" [Determined to Defend Themselves], Večernje novosti (Belgrade), No. 23944, August 18, 1990, p. 4.

Milić od Mačve. "Tuđman ne zna istoriju” [Tuđman does not Know his History], Politika (Belgrade), No. 27534, June 3, 1990, p. 13.

Muradbegović, Midhat. "Tuđman se uključuje u san o velikoj Hrvatskoj” [Tuđman Steps on the Greater Croatia Bandwagon], Politika, No. 27490, April 18,1990 , p. 19. 
Muradbegović, Midhat. "Tuđmanovo pretvaranje Muslimana u "islamske Hrvate" [Tuđman is Turning Muslims into 'Islamic Croats], Politika (Belgrade), No. 27489, April 17, 1990, p. 15.

Domovinski rat: Pregled političke i diplomatske povijesti [Croatian War of Independence: an Overview of the Political and Diplomatic History], Ante Nazor and Tomislav Pušek, eds. Zagreb: Globus, HMDCDR, 2018.

Nazor, Ante. Velikosrpska agresija na Hrvatsku 1990-ih /Greater Serbian Aggression on Croatia in the 90's. Zagreb, 2011.

Nenadović, Aleksandar. "Politika u nacionalističkoj oluji", in: Srpska strana rata: Trauma $i$ katarza u istorijskom pamćenju [Politics in a Nationalistic Storm: Serbian Side of the War, Trauma and Catharsis in Historical Memory]. Belgrade: Republika, Vikom grafik, Građanska čitaonica Zrenjanjin, 1996, pp. 583-610.

Perić, Ivo. "Političko ozračje u vrijeme osnivanja početnog djelovanja $\mathrm{Hr}$ vatske demokratske zajednice" [Political atmosphere at the time of the forming and initial activities of the DZHHDZ party], in: Spomen knjiga: Deset godina Hrvatske Demokratske zajednice, [Commemorative book, Ten years of the HDZ party ], Anđelko Mijatović, ed. Zagreb: Hrvatska demokratska zajednica, 1999.

Petrović, Radivoje, Radivojša, Branislav. "Otvoreni telefon Politike o Srbima u Hrvatskoj: Borićemo se do kraja za suverenost srpskog nacionalnog bića u Hrvatskoj" [Open phone lines for discussing the issue of the Serbs in Croatia: We Shall Fight to the end for the Sovereignty of the Serb National Entity in Croatia], Politika (Belgrade), No. 27594, June 18 1990, pp. 7-8.

"Programske zasade i ciljevi HDZ, Uvodno izlaganje dr. Franje Tuđmana" [Political platform and objectives of the HDZ, Introductory speech by Franjo Tuđman], Glasnik Hrvatske demokratske zajednice (Zagreb), No. 8, March, 1990, pp. 17-21.

Radulović, Srđan. Sudbina Krajine [The Fate of Krajina]. Belgrade: Dan Graf, 1996.

Ramet, Sabrina P. Balkanski Babilon: Raspad Jugoslavije od Titove smrti do Miloševićevog pada [Balkan Babel. The Disintegration of Yugoslavia from the Death of Tito to the Fall of Milošević]. Zagreb: Alinea, 2005.

Rittgasser, Stefan, "Nove jednorječnice u jezikoslovnom nazivlju" [New one-word Lexemes in Linguistic Terminology], Časopis za kulturu hrvatskoga književnog jezika 58 (October 2011), No. 4: 121-129.

Republika Hrvatska i Domovinski rat 1990. - 1995.: Dokumenti institucija pobunjenih Srba u Republici Hrvatskoj (1990. - 1991.) [The Republic of Croatia 
and the Croatian War of Independence 1990-1995, Documents of the Rebel Serbs in the Republic of Croatia], Rupić Mate, ed. Zagreb: HMDCDR, 2007)

Sliber, Laura, Little, Allan. Smrt Jugoslavije: Svjedočanstva [Death of Yugoslavia: Testimonies]. Opatija: Otokar Keršovani, 1996.

Smiljanić, Radomir, "Srbi neće da finansiraju Tuđmanovu NDH" [The Serbs will not Finance Tuđman's NDH], Politika (Belgrade), No. 27443., March 2 1990, p. 13.

Spasojević, Svetislav, “Gost NIN-a, Borislav Mikelić” [NIN’s Guest, Borislav Mikelić], NIN (Belgrade), No. 2046, March 18, 1990, pp. 12-15.

Veledar, Aladin. "Svojatanje Bosne je nerazuman akt" [Laying Claim to Bosnia and Herzegovina is a Folly], Politika (Belgrade), No. 27535, June 4, p. 13.

Vučelić, Milorad. "HDZ i NDH” [HDZ and NDH], NIN (Belgrade), No. 2044, March 4, 1990, p. 9.

Vučelić, Milorad. “Zašto pobeđuje Tuđman?” [Why is Tuđman Ahead], NIN (Belgrade), No. 2052, April 29, 1990, p. 10.

Zec, Stevan: "Maksimirska vatra mržnje" [The Maksimir Fire of Hatred], Politika (Belgrade), No. 29515, May 15, 1990, p. 11.

Žunec, Ozren. Goli život I: Socijetalne dimenzije pobune Srba u Hrvatskoj [Survival and Social Dimensions of the Serb Rebellion in Croatia]. (Zagreb: Demetra, 2007) 